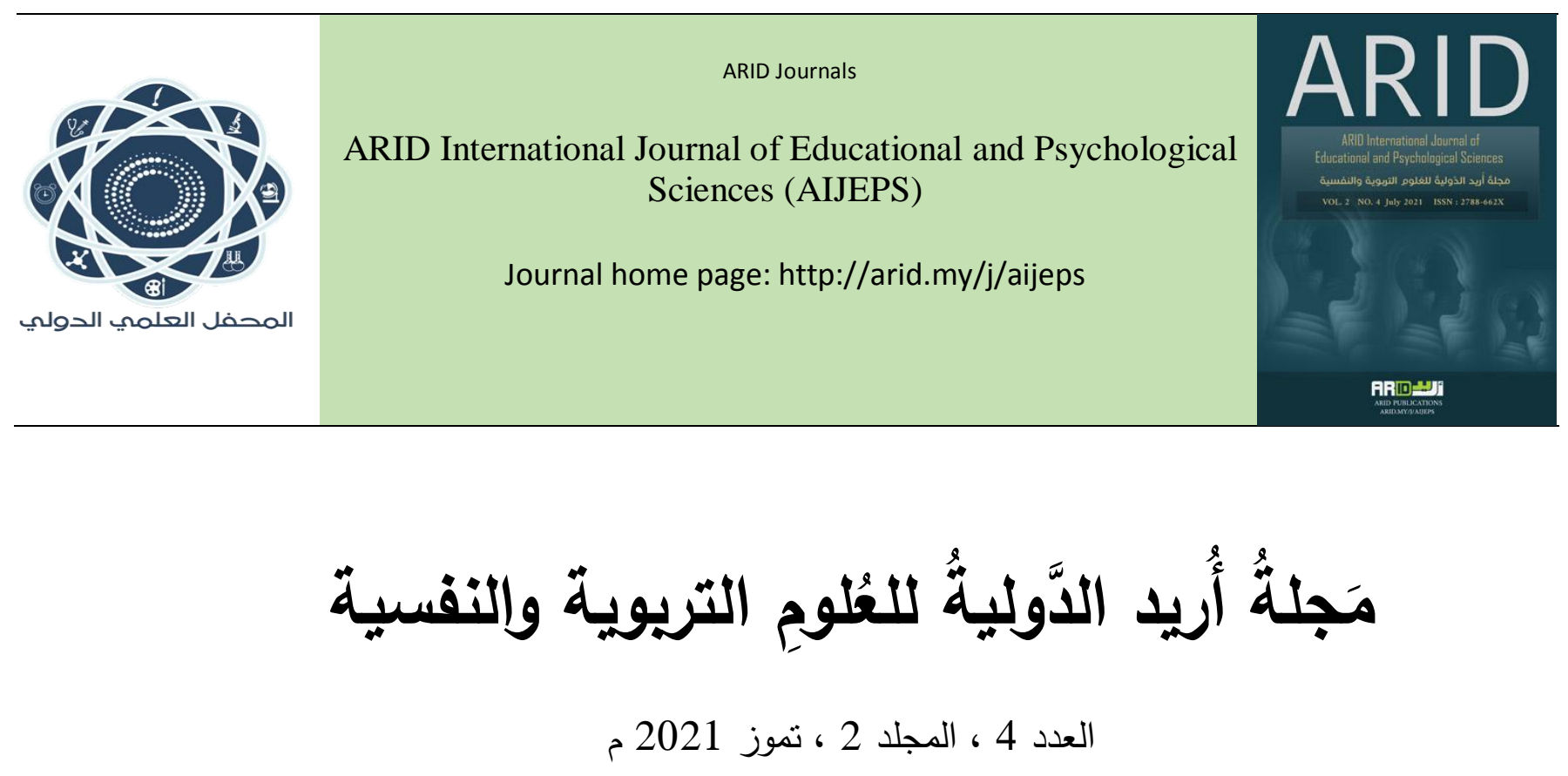

\title{
Professional competencies of the imam and preacher of the mosque and methods of developing religious education in Iraq
}

\author{
Majid Ayoub Al-Qaisi \\ Iraq - Diyala University - College of Education for Pure Sciences \\ الكفايات المهنية لإمام وخطيب المسجد وأساليب تطوير التعليم الايني في العراق \\ ماجد أيوب القيسي \\ كلية التربية للعلوم الصرفة- جامعة ديالى- العراق
}

majid_ayoub12@yahoo.com

arid.my/0003-1075 


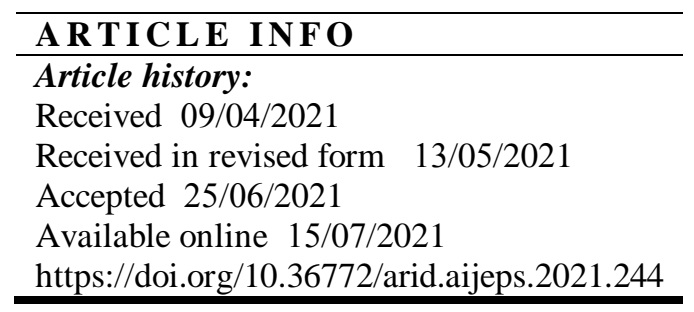

\begin{abstract}
The imam and preacher of the mosque plays a great educational and social role that requires his possession of professional competencies that qualify him to communicate with listeners of different ages, cultures, functional and scientific levels, and this task is more difficult than the task of the teacher who deals with a group of students of similar ages and cultures with a predetermined approach, and religious education that produces imams and preachers. Either high school or university students often attract the weakest students at the scientific level, and it is intended for him to succeed in his educational and social mission, and accordingly the current research aims to determine the professional competencies of the imam and preacher of the mosque, as the researcher did not find a previous study in this field, and to suggest methods for the development of education In Iraq, in order to draw an educational implementation plan, and use the descriptive and analytical approach, and to achieve these two goals, two research tools were built, each of which (40) paragraphs divided the first into three areas and the second into seven, presented to a sample of (30) experts in religious education. And the university, and the results of the competencies showed: The progress of the mastery sections in the field of specialization, and the sincere desire for reform, and the paragraphs won: The polarization of outstanding students, adding scientific subjects and the English language to the curricula, paying attention to public speaking skills, defining a value system and its application, the highest percentages in methods of developing religious education, and the researcher recommended studying the difficulties facing the Imam and the preacher in his work, and developing a practical vision to confront destructive cultures and ideas.
\end{abstract}

Key words: competencies, professionalism, imam and preacher, development, religious education. 


\section{الملخصن}

يقوم إمام وخطيب المسجد بدور تربوي و اجتماعي كبير, يتطلب امتلاكه الكفايات المهنية التي تؤهله للتو اصل مع مع مستمعين مختلفي

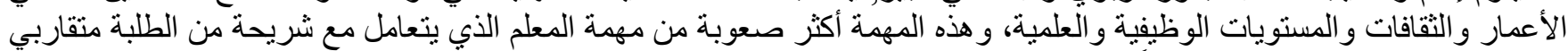

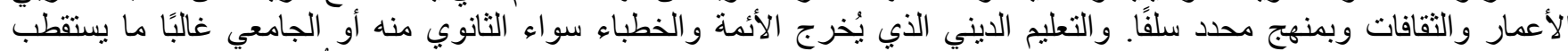

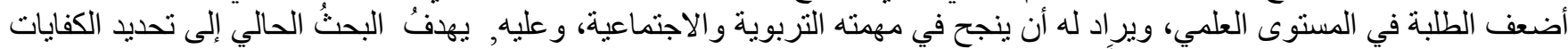

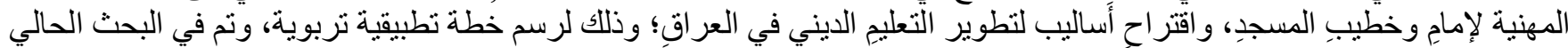

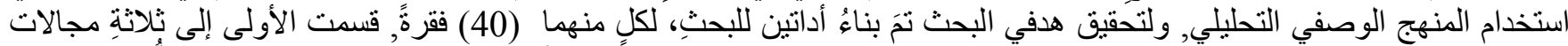

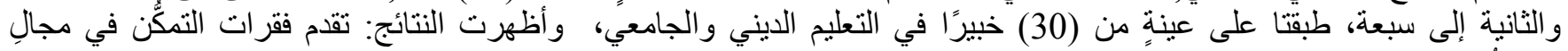

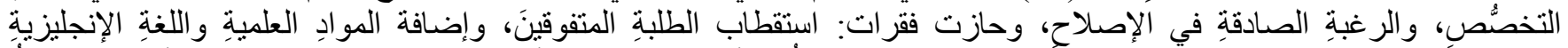

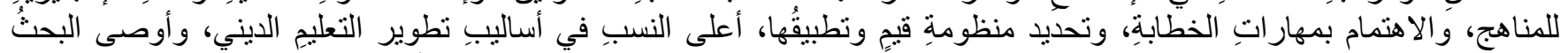

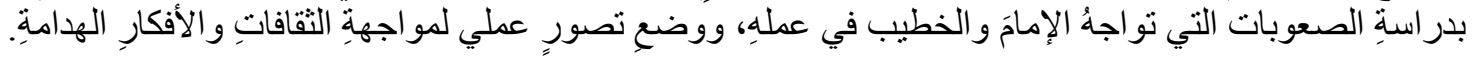

كلمات مفتاحية: كفايات مهنية، إمام وخطيب، نطوير، التعليم الديني. 
الحمد لله و الصلاة والسلام على رسول الله و على آله وصحبه أجمعين، تشهد جميع البلدان العربية و الإسلامية انتشارًا واسعًا للمساجد, وتشهد هذه المساجد نو افد المصلين بأعداد كبيرة, خاصة في صلاة الجمعة التي يتخللها خطبة يُلقيها خطيب المسجد للحاضرين, الذين تتفاوت أعمار هم من الطفل إلى الثيخ الكبير، كما تتفاوت مستوياتهم الثقافية والعلمية، ومؤهلاتهم الدراسية بشكل كبير، في الوقت الذي نشهد فيه انفجارًا للمعرفة بكل فروعها وتخصصاتها، و انفتاحًا للناس على مختلف الأفكار والثقافات، عبر القنوات الفضائية وشبكات التو اصل الاجتماعي، مما يُوجب على الخطيب مر اعاة ذلك, و التزود بكل جديد من العلم والثقافة, و إلا فسيواجه مستمعين أكثر منه ثقافةً و اطلاعًا، ما يُوجب ضرورة تأهيل إمام وخطيب المسجد تأهيلاً يساعده على النجاح في مواجهة هذه المهمة، ولذلك هَذَ هذا البحث إلىى تحديدِ الكفاياتِ المهنيةِ لإمامِ وخطيبِ المسجِد، و اقتر احِ أساليب لتطويرِ التعليمِ الديني في العراقِ الذي يتبنى تخريج الأئمة والخطباء، ولتحقيق الهدف الأول؛ نم بناءُ أداةِ البحثِ بالرجوع إلى الدراساتِ السابقِة والإطارِ النظري للبحثِ، وأساليب تحديدِ الكفايات، من (40) فقرة مقسمة إلى ثناثةِة مجالاتٍ هي الكفاياتُ المعرفيةِ، وكفاياتُ الأداءِ، والكفايات الوجدانيةِ, ونم التأكد من صدق وثبات الأداة، ثم عرضت على عينة مكونة من مجموعةٍ منَ الخبراءِ تم اختيار هم بأسلوبٍ قصدي، من العاملينَ في التعليم الديني والجامعي، بلغَ عددهم (30) خبيرًا، ولتحقيق الهدف الثاني تم بناءُ أداة ثانية للبحثِ منْ (40) فقرةٍ مقسمةٍ إلى سبعةِ مجالات هيَ: استقطابُ الطلبةِ المتفوقينَ، تأهيلُ المدرسينَ، تطويرُ المناهج، تحديثُ وسائلِِ وأساليبِ التدريس، اكتسابُ المهاراتِ، زيادةُ مر افقِ المدرسِِ، تطبيقُ القيم، واستخدمت الوسائل الإحصائية المناسبة، فأظهرتْ النتائج في مجالِ الكفاياتِ المعرفيةٍ: التمكُن في مجالِ التخصُص، و التزود و الاطلاع الدائمِ على المعلوماتِ، وفي مجالِ كفاياتِ الأداءِ: التحرُّر من الصورِ التقليدية للإِمام والقدرة على تبسيطِ المعارفِ واستخدام الأمتلة، وفي مجال الكفايات الوجدانيَّة: الصدق و الإخلاص و الرغبة الصادقة في الإصلاح. وفي مجال أساليب تطويرِ التعليمِ الديني: فإن استقطبِ الطلبةِ المتفوقينَ، حازت على أعلى النسب المئوية من خلال فقرات: دفع مخصصاتٍ ماديةٍ، وتعيين الخريجينَ، وفي مجالِ تأهيلِ المدرسينَ تقدمت فقرةُ: تفعيلِ مساءلة المدرسِ الأولِ في كلِ اختصاصٍٍ, وفي مجال تطوير المناهج: إضـافة الموادِ العلميةِ واللغةِ الإنجليزيةِ والرياضياتِ، وفي مجال وسائلِِ وأساليبِ التدريسِ: التعلمُ الذاتي و التعلمُ الجماعي, وفي مجالِ اكتسابِ المهار اتِ: مهارات الخطابة ومهارات التنميةِ البشرية، وفي مجالِ زيادةِ مر افقِ المدرسِِ: فتحُ ملاعبٍ و مختبر اتٍ علميةٍ، وفي مجالِ تطبيقِ القيِم: تحديدُ منظومةِ قيٍٍ وتطبيقُها، ومحاربةُ تناقضِ القولِ و الفعلِ. واقتر ح الباحثُ در اسةَ هذا البحث من قبلِ الوقفين السني والثيعي، ودائرني التعليحِ الديني و الدراسات الإسلاميةِ في الوقفين، وعرضه على كليات العلوم الإسلامية في العر اق للنظر في إمكانيةِ تطبيقِه، وأوصي برر اساتٍ أخرى حولَ الموضوع منها، و الله ولي الهداية والتوفيق. 


\section{مشكلةُ البحث:}

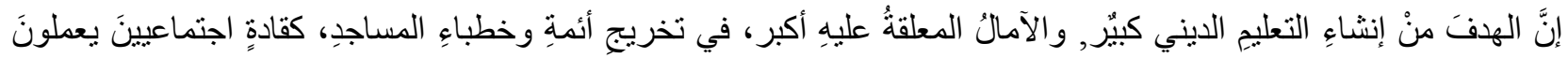
في النصح و الإرشادِ والتوجيهِ لمختلفِ الشرائح الاجتماعيةِ، ولمختلفِ الأعمارِ والمؤهلاتِ العلميةِ بما يعودُ بالخيرِ والصلاح على المجتمع، ومحاربةِ الأفكارِ الهدامةِ، والتطرفِ، والتزمت، و هذِِ المهمة تتطلبُ إعدادًا علميًا وثقافيًا ومهاريًا كبيرًا، لكنَ واقع الحالِ يُظهر أنَ هذا التعليم يستقطبُ أضعفَ الطلبةِ في المستوى العلمي، ويلجأُ إليهِ الطلبةُ المهمونَ أو الفاشلونَ في التعليمِ العام؛ لسهولةِ

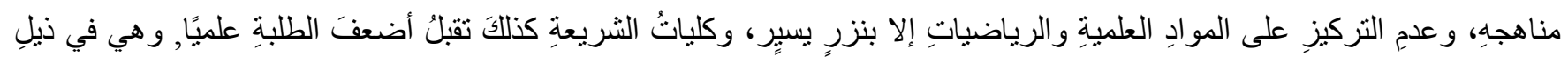
قائمةِِ معدلاتِ القبولِ للكلياتِ والمعاهدِ، وتفتحُ الدر اساتِ المسائيةِ للطلبةِ الأكثرُ ضعفًا، ومناهجها مكملةُ لمناهج الثانوياتِ الدينيةِ، ويتمُ التركيُز فيها على الجوانبِ النظريةِ دونَ النطبيقيةِة ثم يعينُ المتخرجُ كإماٍِ وخطيبٍ في المساجدِ أو كمدسٍِ لمادةِ التربيةِ الدينيةِ في المدارس، فيظهرُ على الكثيرِ منهْ الضعفُ الو اضحُ في المستوى العلمي والثقافي والثرعي والالتز احِ الوظيفي، ومنْ جانبٍ آخر فليسَ

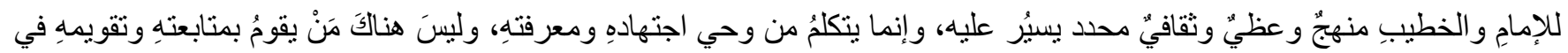

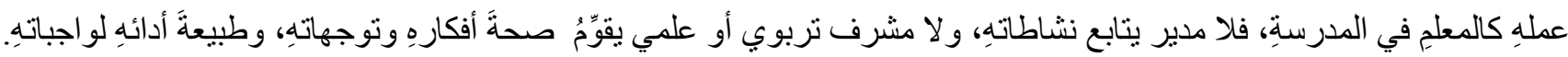
و هذا الخللُ يدعونا لتحديدِ مجموعةِ الكفاياتِ المهنيةِ لهذه الوظيفةِ، و لإعادةِ النظرِ في البرامج التربويةِ في التعليمِ الديني، ليتمكنَ المتخرجُ منْ أداءِ واجباتهِ بكفاءةٍ و إتقانٍ، والعمل على حلِ المشاكلـالدينيةِ والاجتماعيةِ ومحاربةِ الفتنِ التي تواجههُ، و عليهِ, يمكنُ إجمال مشكلةِ هذا البحثِ في السؤالين الآتيين:1 - ما ما الكفاياتُ المهنيةُُ لإمامِ وخطيبِ المسجدِ؟ 2 - ما أَساليبُ تطويرِ التعليمٍ الديني في العراقِ؟

هدفا البحث: - اقتراح أساليب تطويرِ التعليمِ الديني في العراقِ.

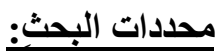

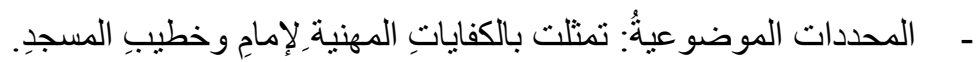
- المحددات البشريةُ: تمثلت بـ (30) خبير اً منْ خبر اعِ التعليمِ الديني و الجامعي. 


$$
\text { أهميةُ البحث: }
$$

\section{تعريف المصطلحات:}

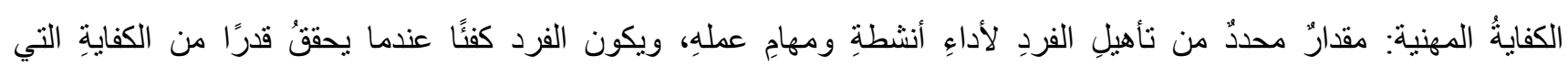

$$
\text { بمكن" إدر اجُها وقياسُها في مجتمعٍ ما (قوارح و غريب, 2017, 486). }
$$

التعليُم الديني: يَقصدُ به الباحثُ: التعليم الذي يجري بالمدارس الثانوية التابعة لدائرتي التعليمِ الديني والدر اسات الإسلاميةِ في الوقفين

$$
\text { السني والثيعي، وكليات العلوم الإسلامية في العراق. }
$$

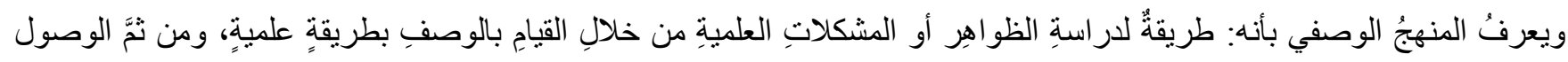
إلى تفسير اتٍ منطقيةٍ لها دلائل وبر اهين, تمنح الباحثَ القدرةَ على وضع أطرٍ محددةٍ للمشكلةِ، ويتمُ استخدامُ ذلكَ في تحديدٍ نتائج البحثِ (حمداوي, 2013, 22). 


\section{الأراساثُ السابقُة:}

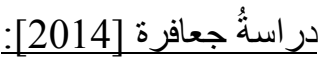

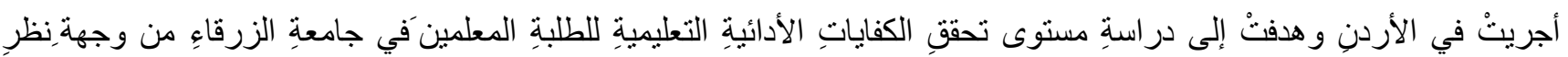

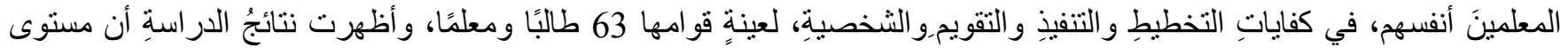
تحققِ الكفاياتِ الأدائِة التعليمية للطلبة المعلمين كانت عاليةً في مجالاتٍ الدراسة ككل، ما عدا مجاٍٍ واحدٍ وهو مجالُ الثخصيةٍ

$$
\begin{array}{r}
\text { (جعافرة, 2014, } 553 \text { - 589). } \\
\text { دراسةُ الأحمدي [2016]: }
\end{array}
$$

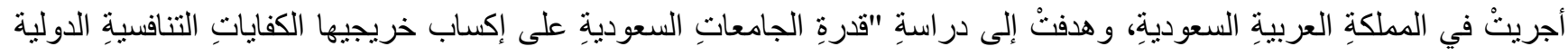
لسوقِ العملِ بالسعودية"، وتمثلتُ الكفايات التنافسية في الكفاياتِ الأدائية و التنظيمية وكفايات الاتصالِ، و أظهرتُ النتائج أن هناك (9) كفاياتٍ تنظيميةٍ اسنطاعتُ الجامعاتُ السعودية إكسابها لطلبتها بدرجةٍ عاليةٍة، أما كفايات الاتصالٍ فقد قدرتْ بدرجةٍ متوسطةٍ (الأحمدي, $(205-259,2016$

\section{در اسةُ أبو صواوين [2017]:}

أجريتْ في مصر، و هدفتُ إلى دراسة "الكفاياتِ التعليميةِ اللازمة للطلبةٍ المعلمينَ تخصص معلم الصف في كليةٍ التربيةِ بجامعة

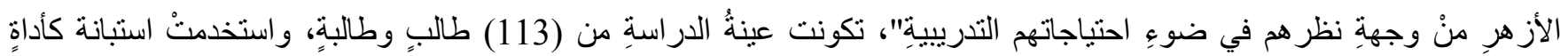
للبحث: فيها ثمانية مجالات، وأظهرت الدراسة: مدى احتياجات عينة الدراسةِ لكفاياتِ عرضِ الدرسِ، وكفاياتٍ التقويم, وكفايات استثارة انتباهِ التلاميذّ وتهيئتهم للاروس، و هذا يشيرُ بوضوحٍ إلى ضعفِ الإعداد المسلكي للطلبة المعلمين (أبو صواوين, 2017, 259- 205). موازنةُ الار اسات السابقة: 1 - - ملها در اساتُّ عربيةٌ (الأردن، السعودية، مصر).

2 - استهدفتْ الدراستان الأولى و الثالثة الطلبة المعلمين في أثناء الدراسةِ، بينما استهدفتُ الدراسة الثانيةٍ الجامعات السعودية.

$$
3 \text { - لها منهجُ بحثٍ واحد هو المنهج الوصفي التحليلي. }
$$

4 - لها منهجية البحثٍ نفسها, وهي بناءُ استبانة وعرضها على عينة البحث.

5 - تباينت العيناتُ في أعدادها: ( 63 طالبًا وطالبة، جامعتان سعوديتان، 113 طالبٍ وطالبةٍ على التو الي). 
6 - أظهرت النتائج حاجةً الطلبة المعلمين للكفايات المهنية، وأن الجامعات السعودية نساعد طلبتها على اكتساب أكثر الكفايات, وأن هناك ضعفًا في اكتساب كفايات التو اصل.

جو انبُُ الإفادةٍ من الدر اساتِ السابقةٍ: 1 - إعداد الإطارِ النظري للبحث.

2 - التأكُُ من منهجية البحث.

الإطارُ النظري للبحث:-

إنَّ لكلٍ عملٍ أو وظيفةٍ كفايات مهنيةُ، لا بدَ لمن يؤديها من امتلاكها، وعلى درجةِ تو افر هذِِ الكفاياتِ تتوقفُ نواتجُ ذلكَ العمل و الاستفادةٍ منُه، و هي قدراتُّ مكتسبةٌ، يمكنُ توظيفها من أجلِ إتقانِ العملِ والدقةِ فيه، وهي تؤهلُ صاحبها لممارسةِ عملهِ بنجاحٍ (عطية,

ولا شلكَ أنَّ كلَ المهنِ تتطلبُ العملَ على تجديدِ هذِِ الكفاياتِ المهنية, وحثَ العاملينَ ونوجيههم نحو امنلاكها بسببِ الظروفِ الاجتماعيةِ التي تستجد، ومن هذه المهن مهنةُ الإمام و الخطيب، و لا بد من دراسةِ واقع التعليم الديني الذي يتخرج منه، فقد حدَّدت منظمةُ اليونسكو مشكلًَ التعليم في الوطنِ العربي عامةً بأنها نتلَّص في طغيانِ الطابع النظري، والاعتمادِ على التلقينِ المستمر، وبدائيةِ الأساليبِ المستخدمةِ فيهِ, و عدم قدرةِ الطلبةِ على الاستفادةِ من المحتوى التعليمي المقدَّم لهم، حيثُ يتم تخريجهم دونَ درايةٍ بما يجبُ عليهم أن يفعلوهُ بعد التخرُج.

و اقترحتْ در اسةٌُ سالم (2013) تخصيص ميز انيةٍ كافيةٍ للمؤسساتِ التعليميةِ، وتوفيُر العملِ المناسبِ للحاصلينَ على شهاداتٍ عاليةٍ، ودفع حالةِ الإحباطِ من التعليحِ والاستهانةِ بهِ، والمتابعة المستمرةِ للمدرسينَ, ومكافأة ذوي الكفاءةِ منهم، والاهتمام بالمناهج، وتوفِِر المختبر اتِ العلميةِ و المكتباتِ، وجعلها متاحةً لكلِ الطلبةِ (سالم, 2013, 8).

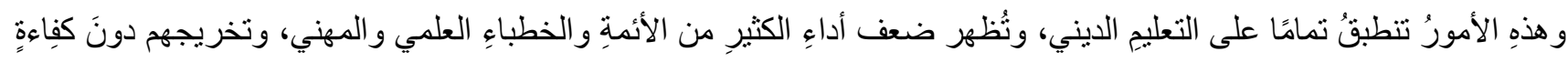
ودر ايةٍ بما يجبُ أن يفعلوه، وضعف في مواجهةِ مختلفِ الثرائح الاجتماعيةِ ومستوياتها الثقافيةِ المختلفِة، وهي مهمةُ تحتاجُ إلى كفاياتٍ مهنيةٍ متعددةٍ للنجاح بها، تثملُ مجموعة مهامٍ معرفيةٍ، ومهاريةٍ، ووجدانيةٍ، ليكونَ الأداءُ النهائي المتوقعُ إنجازهُ بمسنوى مقبولٍ تربويًا و اجتماعيًا, ويمكنُ تقدير هذِِ الفعاليةِ وملاحظتُها وتقويمها، فالإنسانُ الكفء هو من يمتلكُ مهارة في العملِ، وثقة كبيرة في النفسِ تمنحهُ

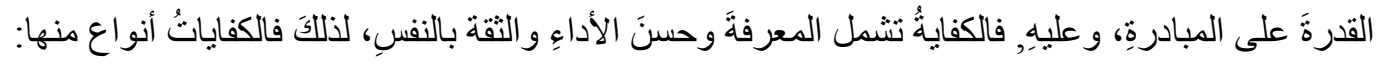


1 - كفايات نَرَتَبطُ بالمعارفِ.

2- كفايات تَرَتَبط بالأداءِ.

3- كفايات نَرتَبط بالنتائج. (غازي, 1998, 60)

وتصنفُ الكفاياتُ إلى مجالاتٍ منها:

1ـ التمكُن من المعلوماتِ النظريةِ عامة.

2- التمكُن من المعلوماتِ في مجالِ التخصُّص.

3ـ امتلاكُ الاتجاهاتِ التي تُسهُ في إقامةِ العلاقاتِ الإنسانيةِة في المجتمع وتحسينها.

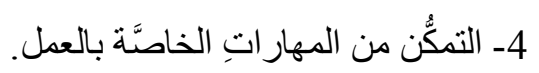

و هنالك أربعةَ أنواعٍ من الكفاياتِ المِهِنية يمكن أن تطبق في وظيفة الإمامة و الخطابة وهي:

1- الكفاياتُ المعرفيَّة "الثقافية": وتدلُّ على المعلوماتِ المعرفيةِ والثقافيةِ الضروريةِ لأداءِ الإمام في كل مجالاتِ عملِه التوجيهي.

2- الكفايات الوجدانيَّة: وثُشِيرِ إلىى: ميول الإمام، واتجاهاتِه، وقيمِه، ومعتقداتِه، وهذه الكفاياتُ تُغطِّي جوانبَ متعدِّدة مثل اتجاهِه نحوَ

المِهْنَة، وحبُّه لها يجعل عطاءَه عطاءً متينًا وقويًَّا.

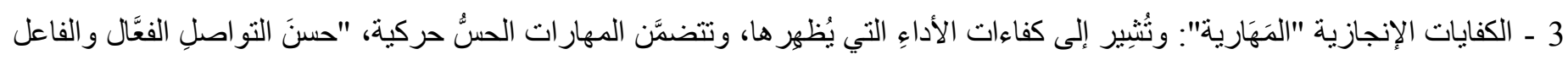

مع المتابعين، وتمكِّنه من توظيفِ و سائلِ التعليم وتكنولوجياته، و انفتاحه على مُحبط المتابعين. (قنديل, 2000, 100).

ومن ذلك أيضًا:

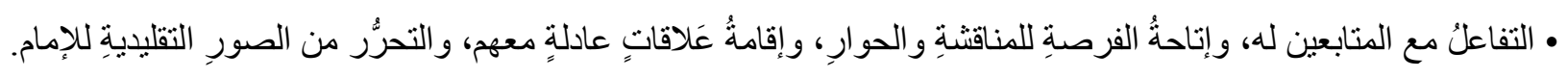
• الرغبةُ في التعلمِ، و القدرةُ على التعلُّم الذاتي. • (الاتزانُ الانفعالي. • القدرةُ على تبسيطِ المعارفِ واستخدامُ الأمثلة. • القدرةُ على تطويرِ ذاتِه، وتحسينُ الطر ائقِ التي يتبعُها في الإرشادِ, وفي تحفيزِ المتعلّمينَ على المبادرةِ والمشاركةُ في اتخاذِ القرارِ. • القدرةُ على تحقيقِ التو اصلِ الفَّالِِ مع الأسرةِ والمدرسةِو المجتمع. (البرجاوي, 2014, 15) 


\section{أساليب تحديد الكفايات:}

$$
\text { هناكَّ عدةُ أساليب لتحديدٍ الكفاياتِ، إلا أن أكثر ها شيوعًا هي: }
$$

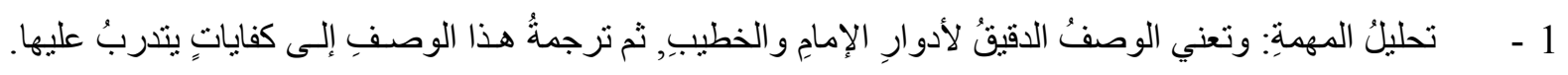

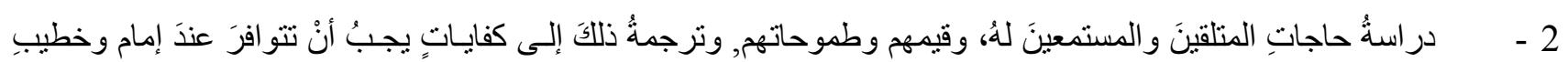

$$
\text { المسجد. }
$$

$$
\begin{aligned}
& 3 \text { - در اسةُُ حاجاتِ المجتمع المحيطِ بالمؤسسةِ الدينيةِ ونعرفتُ منطلباتهِ وتحديـدُ المهار اتِ اللازم تو افر ها. } \\
& 4 \text { - التصورُ النظري لمهنِِِ الإمامِ والخطيبِ و التحليلُ المنطقيُ لأبعادِ هذا التصور (قنديل, 2000, 100). }
\end{aligned}
$$

\section{إجراءات البحث:}

إجر اءات الإجابة عن السؤال الأولِ: سيتُُ في هذِِ الفقرةِ الإجابةِ عن السؤالِ الأولِ من أسئلةِ البحثِ وهو: "ما الكفايات المهنية لإمام وخطيب المسجدِ؟" وفق الإجراءاتِ الآتيةِ:

أداة البحث: نم بناءُ أداةِ البحثِ بالرجوع إلى الدراساتِ السابقِة والإطارِ النظري للبحث؛ وأساليب تحديد الكفاياتِ، ونَّ وضع مجموعِّ مقترحاتٍ في استبانةٍ مكونةٍ من (30) فقرة، و عرضها على عينةٍ استطلاعيةٍ من الخبراءِ في التعليٍِ الديني والجامعي، وتحليل استجاباتِ أفر ادِ العينةِة الاستطلاعية، و على أساسها تم تعديلُ مجموعةٍ من العبارات وأضيفت إليها عباراتُ أخرى، وبذلك تكونتْ الأداةُ بصيغتها النهائيةِ من (40) فقرة مقسمة إلى ثلاثة مجالاتٍ هي الكفاياتُ المعرفيةِ، وكفاياتُ الأداعِ، و الكفاياتُ الوجدانيةِ، ووُضِعَ لها مقياس ثلاثي (مو افق، متردد، معارض)، وأعطيتْ الدرجات الآتية: (3) درجاتٍ لكلِ إجابةِ مو افق، و(2) درجتان لكلِ إجابةِ متردد، و(1) درجة واحدة

لكلِ إجابِة معارض. ملحق رقم( 1)،(2 )،( 3). وثنمَّ التأكدُ منْ صدقِِ وثباتِ الأداةِ:

صدقُ الأداة: ويُقصدُ به: "أن تقيسَ الاستبانة ما وضعَت لقياسِِه، أو: "أن تعكسَ الاستبانة المحتوى المراد قياسه وفقًاً لأوزانهِ النسبيةِ"، ومنْ أكثر طرقِ قياسِ الصدقِ شيوعًا هي طريقةُ استطلاع آراءِ المحكمينَ الخبراء، المختصينَ في مجالِ الظاهرةِ أو المشكلةِ موضوع

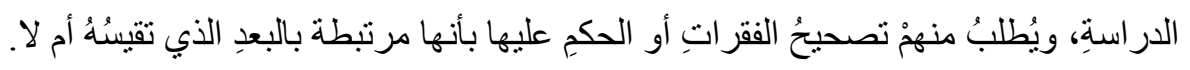
وِيُصدُ بثباتِ الأداةِ: أنْ تعطيَ الاستبانة النتائج نفسها إذا أُعبدَ نطبيقها مرات متتالية، مما يدلُ على اتساقِ النتائج، ومنْ أيسرِ طرقِ التحققِ منْ ثباتِ الاستبانة: طريقةُ إعادةِ نطبيقها، و التوصلِ إلى نتائج متماتلذةٍ (أبو صواوين, 2017, 22). 


\section{اختيارُ عينُةُ البحث:}

تمنلتُ عينةُ البحثِ في مجموعةٍ منَ الخبر اءِ تم اختبار هم بأسلوبٍ قصدي، من العاملينَ في التعليم الديني و الجامعي، بلغَ عددهم (30) خبيراً. (ملحق رقم 4)، من ذوي الألقابِ العلميةِة، وممنْ مارسوا التعليحَ والإشرافَ لفترةٍ تربو على (25) عاماً من مختلفِ الجامعاتِ و المحافظاتِ، ولهز مشاركاتٍ في وضعِ المناهج ونأليفِ الكتبِ العلميةِ، والأنشطة البحثيةِ و المشاركة بالندواتِ والمؤتمرات في الداخلِ و الخارج، و الإشر افِ على رسائلِ الماجستِِر و الدكتور اه، والإشر اف و التحكيمِ في المجلاتِ العلميةِ بالاختصاصِ.

$$
\text { واتبعت الإجر اءات الآتية: }
$$

أـ عرضُ الأداةِ على عينة البحث.

ب- جمعُ الآر اعِ واستخدامُ الوسائلِ الإحصائيةِ المناسبة.

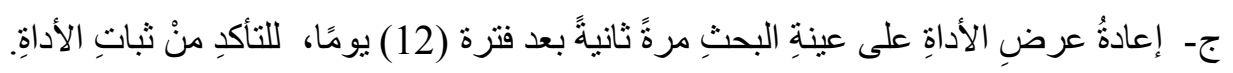
د- تقديم التوصيات و المقترحات.

\section{الوسائلُ الإحصائية:}

ـ استخدمتْ معادلةُ المتوسطِ الحسابي، ومعادلةُ الوزنِ المئوي للفقرةِ في تحليلِ إجاباتِ الخبر اعِ، و الوصولِ إلى النتائج:معادلةُ المتوسطِ الحسابي:-

المتوسط الحسابي= عدد استجابات (مو افق)*3+ عدد استجابات (محايد)*2+ عدد إجابات معارض* / / التكرار الكلي لأفراد العينة. معادلةُُ الوزنِ المئوي للفقرة:-

الوزن المئوي للفقرة = المتوسط الحسابي/ الدرجة القصوى *100 (الصياد, 2017, 25). نتائجُ الإجابة عنْ السؤال الأولِ:

بعد جمع المعلوماتِ الواردةِ في الاستبانةِ، وتحليلها, ظهرتْ النتائجُ كما في الجدولِ رقم (1): 
جدول(1): المتوسط الحسابي والوزن المئوي للكفايات المهنية لإمام وخطيب المسجد

\begin{tabular}{|c|c|c|c|}
\hline 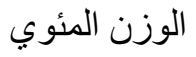 & المتوسط الحسابي & أنو اع الكفايات & $ت$ \\
\hline \multicolumn{4}{|c|}{ كفايات معرفية } \\
\hline 89 & 2.68 & التمكُّن في مجالِ التخصُُص. & 1 \\
\hline 89 & 2.68 & التزود والاطلاع الدائم على المعلوماتِ. & 2 \\
\hline 72 & 2.16 & التزود بالمعارف العلمية و الرياضيات و اللغات. & 3 \\
\hline 72 & 2.16 & الإلمام بالثقافة العامة الضروريةِة & 4 \\
\hline 80 & 2.4 & فهح ومتابعة الحركات الهدامة. & 5 \\
\hline 68 & 2.04 & القدرة على جمع الآراء في المساءلة. & 6 \\
\hline 72 & 2.16 & القدرة على الترجيح بين الآر اء. & 7 \\
\hline 80 & 2.4 & وضع درجات في مز اولة المهنة. & 8 \\
\hline 80 & 2.4 & متابعة الأحداث. & 9 \\
\hline 80 & 2.4 & تحديد سياقات للإنشر اف و المتابعة. & 10 \\
\hline \multicolumn{4}{|c|}{ كفايات الأداء } \\
\hline 89 & 2.68 & التحرُّر من الصور التقليدية للإمام. & 1 \\
\hline 80 & 2.4 & طيب الكلام وحسن التعامل. & 2 \\
\hline 72 & 2.16 & التمكن من اللغة العربية. & 3 \\
\hline 80 & 2.4 & سعة الصدر. & 4 \\
\hline 72 & 2.16 & التمكُّن من مهار اتِ الوعظ و الإرششاد. & 5 \\
\hline 80 & 2.4 & التمكن من الحوار الهادئ و المثر. & 6 \\
\hline 72 & 2.16 & احترام الآر اء المخالفة. & 7 \\
\hline 80 & 2.4 & القدرة على القيادة. & 8 \\
\hline 72 & 2.16 & القدرةُ على تطويرِ ذاتِه. & 9 \\
\hline 89 & 2.68 & القدرةُ على تبسيطِ المعارفِ و استخدام الأمثلة. & 10 \\
\hline 80 & 2.4 & الاهتمام بالعلاقاتِ الإنسانيةِة في المجتمع. & 11 \\
\hline
\end{tabular}




\begin{tabular}{|c|c|c|c|}
\hline 72 & 2.16 & حسن المظهر. & 12 \\
\hline 80 & 2.4 & التجديد المستمر لطرائق الإرشاد والنصح. & 13 \\
\hline 72 & 2.16 & الا هتمام بالجو انب الترفيهية المباحة للشباب. & 14 \\
\hline 80 & 2.4 & التواصلِ الصـادق والفعَّال بالمجتمع. & 15 \\
\hline 72 & 2.16 & الإفادة من أساليب ووسائلِ التعليم. & 16 \\
\hline 80 & 2.4 & الاهتمام بانسجام القول والفعل. & 17 \\
\hline \multicolumn{4}{|c|}{ الكفايات الوجدانيَّة } \\
\hline 80 & 2.4 & حب المهنة. & 1 \\
\hline 80 & 2.4 & الر غبة في العمل. & 2 \\
\hline 72 & 2.16 & الاتزان العاطفي. & 3 \\
\hline 80 & 2.4 & الاتزانُ الانفعالي. & 4 \\
\hline 89 & 2.68 & الصدق و الإخلاص. الصل & 5 \\
\hline 80 & 2.4 & الر غبةُة في التعلٍِ. & 6 \\
\hline 89 & 2.68 & الر غبة الصـادقة في الإصلاح. & 7 \\
\hline 72 & 2.16 & 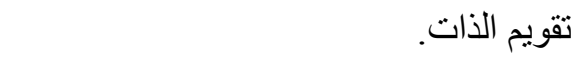 & 8 \\
\hline 80 & 2.4 & الإفادة من تجارب الناجحين. & 9 \\
\hline 72 & 2.16 & تطابق القول و العمل. & 10 \\
\hline 80 & 2.4 & تقديم المصالح العامة على الخاصـة. & 11 \\
\hline 72 & 2.16 & التعالي على صغائر الأمور. & 12 \\
\hline 80 & 2.4 & القدرةُ على التعلُّم الذاتي. & 13 \\
\hline
\end{tabular}




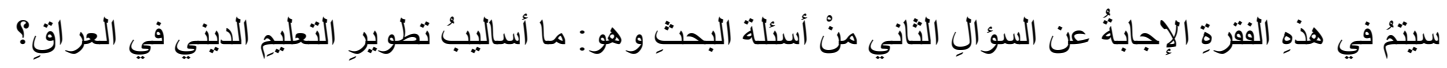
وفقَ الإجر اءاتِ الآتيةِ:

بناءُ أداةِ البحث: وتمتْ بوضع مجمو عةٍ مقترحات في استبانةٍ مكونةٍ منْ (20) فقرة، وتم عرضُها على العينةِ الاستطلاعيةِ، وبعد الأخذ بمقترحاتهم تكونتْ الأداةُ بصيغتها النهائيةِ منْ (40) فقرةٍ مقسمة إلى سبعةِ مجالاتٍ هيَ: استقطابُ الطلبةٍ المتفوقينَ، تأهيلُ المدرسينَ، تطويرُ المناهج، تحديثُ وسائلِ وأساليب التدريسِ، اكتسابُ المهارات، زيادةُ مر افقِ الددرسةِ، وتطبيقُ القيم.(ملحق رقم 5، ملحق رقم 6)، وبعدها: أـ عرضُ الأداةِ على عينةِ البحث. بـ جمُعُ الآراءواستخدامُ الوسائلِ الإحصائيةِ كما سبق.

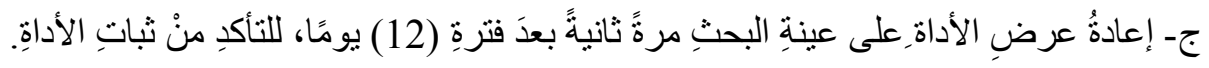
دـ عرضُ نتائج الإجابة، عنْ السؤالِ الثاني: بعد جمع المعلوماتِ الو اردةٍ في الاستبانةِ، وتحليلها ظهرتٌْ النتائجُ كما في الجدولِ رقم (2):جدول(2): أساليبُ تطويرِ التعليمِ الديني

\begin{tabular}{|c|c|c|c|}
\hline 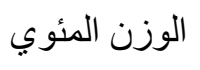 & المتوسط الحسابي & 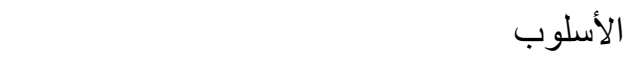 & ت \\
\hline \multicolumn{4}{|c|}{ استقطاب الطلبة المتفوقين } \\
\hline 89 & 2.68 & دفع مخصصات مادية. & 1 \\
\hline 89 & 2.68 & 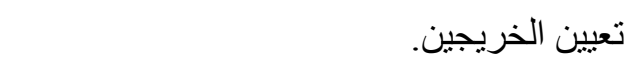 & 2 \\
\hline 72 & 2.16 & فتح الدر اسات العليا وقبول المتفوقين. & 3 \\
\hline 72 & 2.16 & السماح بانتقال الطلبة لمدارس التربية. & 4 \\
\hline \multicolumn{4}{|c|}{ تأهيل المدرسين } \\
\hline 89 & 2.68 & تفعيل مساءلة المدرس الأول في كل اختصاص. & 1 \\
\hline 80 & 2.4 & دورات في الكفاءة العلمية. & 2 \\
\hline
\end{tabular}


ARID International Journal of Educational and Psychological Sciences (AIJEPS) VOL: 2, NO. 4, July 2021

\begin{tabular}{|c|c|c|c|}
\hline 72 & 2.16 & دور ات في التنمية البشرية. & 3 \\
\hline 80 & 2.4 & دورات في طر ائق التدريس الحديثة. & 4 \\
\hline 80 & 2.4 & دور ات في مهار ات استخدام العقل. & 5 \\
\hline 72 & 2.16 & دورات في الدعوة و التوجيه و الإرشاد. & 6 \\
\hline \multicolumn{4}{|c|}{ تطوير المناهج } \\
\hline 89 & 2.68 & إضـافة المو اد العلمية. & 1 \\
\hline 89 & 2.68 & إضـافة اللغة الإنجليزية. & 2 \\
\hline 89 & 2.68 & إضـافة الرياضيات. & 3 \\
\hline 80 & 2.4 & إضـافة الاجتماعيات. & 4 \\
\hline 72 & 2.16 & إضـافة مو اد ثقافية. & 5 \\
\hline \multicolumn{4}{|c|}{ وسائل وأساليب التدريس } \\
\hline 89 & 2.68 & التعلم الذاتي. التي. & 1 \\
\hline 89 & 2.68 & التعلم الجماعي. & 2 \\
\hline 72 & 2.16 & الأفلام و المصور ات. & 3 \\
\hline 80 & 2.4 & التعلم من الطبيعة. & 4 \\
\hline 72 & 2.16 & الحو ار و المناقثة. & 5 \\
\hline 72 & 2.16 & البحث العلمي. & 6 \\
\hline \multicolumn{4}{|c|}{ اكتساب المهار ات } \\
\hline 89 & 2.68 & مهار ات الخطابة. & 1 \\
\hline 89 & 2.68 & مهار ات التنمية البشرية. & 2 \\
\hline 80 & 2.4 & مهار ات الحاسبة الإلكترونية. & 3 \\
\hline 72 & 2.16 & 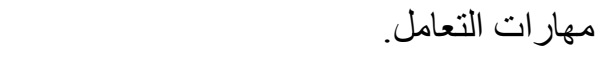 & 4 \\
\hline 72 & 2.16 & المهار ات العقلية كالاستقر اء و الاستنباط. & 5 \\
\hline 80 & 2.4 & مهار ات الذوق العام و النظام واحتر ام القو انين. & 6 \\
\hline
\end{tabular}




\begin{tabular}{|c|c|c|c|}
\hline 89 & 2.68 & ملاعب. & 1 \\
\hline 89 & 2.68 & مختبر ات علمية. & 2 \\
\hline 80 & 2.4 & مقهى للإِنترنت. & 3 \\
\hline 80 & 2.4 & أقسام داخلية. & 4 \\
\hline 72 & 2.16 & 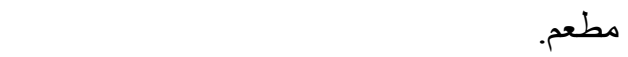 & 5 \\
\hline \multicolumn{4}{|c|}{ تطبيق القيم } \\
\hline 89 & 2.68 & تحديد منظومة قيم وتطبيقها. & 1 \\
\hline 80 & 2.4 & المتابعة المستمرة لتطبيقها. & 2 \\
\hline 72 & 2.16 & إثناعة حب الخير والإصلاح. & 3 \\
\hline 72 & 2.16 & بناء الواز ع الديني و المر اقبة الذاتية. & 4 \\
\hline 72 & 2.16 & نشر حب العلم والبحث العلمي. & 5 \\
\hline 80 & 2.4 & 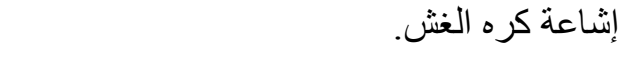 & 6 \\
\hline 89 & 2.68 & محاربة تناقض القول و الفعل. & 7 \\
\hline 80 & 2.4 & احتر ام الذوق العام و الأماكن العامة و المال العام. & 8 \\
\hline
\end{tabular}

أظهرتْ العمليات الإحصائيةِ النتائجَ الآتيةَّ: ففي مجالِ الكفاياتِ المعرفيةِ، حازت الفقرات الآتية على أعلى النسبِ المئويةِ: التمكُن في مجالٍِ التخصُص، و التزود و الاطلاع الدائم على المعلوماتِ، وفي مجالِ كفاياتِ الأداءِ تقدمت الفقرات: التحرُّر من الصورِ التقليدية للإمام و القدرة على تبسيطِ المعارفب و استخدام_الأمثلة، وفي مجال الكفايات الوجدانيَّة: الصدق والإخلاص والرغبة الصادقة في الإصلاح. أما في أساليب تطويرِ التعليمٍ الديني: ففي مجال استقطابِ الطلبةٍ المتفوقين، حازت أعلى النسب المئوية فقراتُ: دفع مخصصاتٍ ماديةٍ، وتعيين الخريجينَ، وفي مجالِ تأهيلِ المدرسينَ تقدمت فقرة: تفعيل مساءلة المدرسِ الأولِ في كلِ اختصاصٍ, وفي مجال تطوير المناهج: إضافةُ الموادِ العلميةِ واللغةِ الإنجليزيةِ والرياضياتِ، وفي مجال وسائلِ وأساليبِ التدريسِ: التعلمُ الذاتي والتعلمُ الجماعي, وفي مجالِ

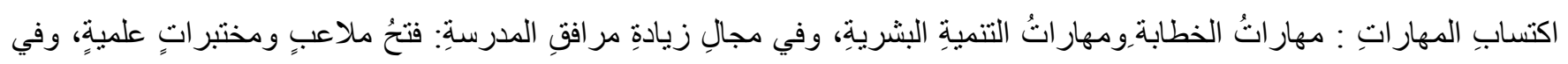
مجالِِ تطبيقِ القيِم: تحديدُ منظومةِ قيمٍ وتطبيقُها، ومحاربة تناقضِ القولِ و الفعلِ. 
يقترحُ الباحثُ عرض البحث على كليات الثريعة في العراق، ودر استه من قِبلِ ديواني الوقفين السني والثيعي، وعرضه على دائرتي التعليمِ الديني و الدر اسات الإسلاميةِة فيهما، و النظر في إمكانيةِ تطبيقهِ.

$$
\text { التوصيات: } 1 \text { يوصي الباحثُ بدر اساتٍ أخرى حولَ الموضوع منها: }
$$$$
2 \text { - وضعُ تصورٍ عملي لمواجهةٍ الثقافاتِ و الأفكارِ السلبيةِة الوافدةِ. }
$$

أتقدُ بخالصِِ الثكرِ والتقدير إلى جميع الأساتذة الكرام الذين شاركوني الآراء, ولم يبخلوا بتقديم الوقت والحوار المثمر البناء، من أجل إخر اج البحث بأفكار وصورة تخدم المجتمع والمؤسسات التربوية. 


\section{قائمة المصادر والمراجع:}

[1] الأحمدي، عائشة بنت سيف صالح (2016)، قدرة الجامعات السعودية على إكساب خريجيها للكفايات التنافسية الدولية لسوق العمل،

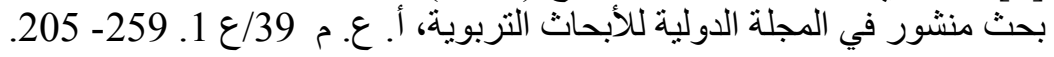

[2] البرجاوي، مولاي المصطفى (2014)، كفايات المدرس بين التراث الإسلامي والمنطلبات المعاصرة، مقال على الإنترنت تحت

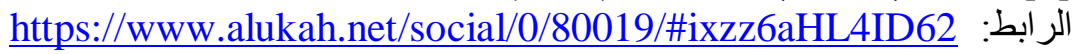

$$
\text { تاريخ الإضافة:20/2014/12 تاريخ الاخول: 2020/10/10 }
$$

[3] جعافرة، عبدالسالم يوسف (2014)، مستوى تحقق الكفايات الأدائية التعليمية للطلبة المعلمين في جامعة الزرقاء من وجهة نظر

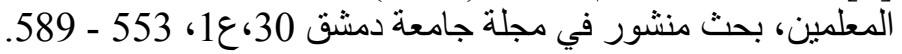

[4] حمداوي، جميل (2013)، البحث التربوي: مناهجه وتقنياته، مطبعة الجسور، الرباط، المغرب. [5] الدريج، محمد (2000)، الكفايات في التعليم، سلسلة المعرفة للجميع، عدد 16. [6] سالم، أحمد جمال (2013)، التعليم في العالم العربي ... مشكلة تبحث عن حل، مقال منشور على الإنترنت تحت الرابط: http://www.alukah.net/culture/0/6416

$$
\text { تاريخ الإضافة: 2013/12/21، تاريخ الاخول : 2020/10/10. }
$$

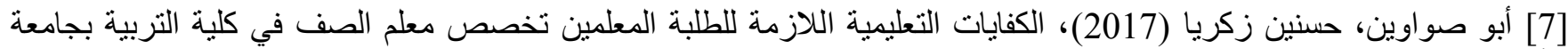

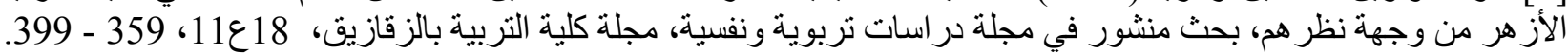

[8] الصياد، جلال (2017)، مقدمة الطرق الإحصائية، دار الثروق، القاهرة، مصر. [9] عطية، محسن علي (2013)، البحث العلمي في التربية، مناهجه، أدو اته، وسائله الإحصائية، دار المناهج، عمان، الأردن. [10] غازي, مفلح (1998)، الكفايات التعليمية التي يحتاجها معلمو المرحلة الابتدائية، كلية التربية، دمشق، سوريا. [11] الفتلاوي، سهيلة (2003), كفايات التدريس، دار الثروق، عمان، الأردن.

[12] قنديل، يس عبدالرحمن (2000)، التدريس و إعداد المعلم، ط3، مكتبة الملك فهد الوطنية، الرياض، م.ع. س. [13] قوارح و غريب، محمد، مختار (2017)، الكفاءات المهنية المنطلبة لمستشاري التوجيه والإرشاد المدرسي والمهني، بحث منشور

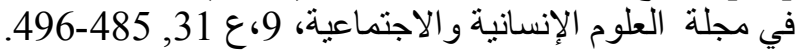


ملحق رقم (1)

العينة الاستطلاعية

\begin{tabular}{|c|c|c|c|c|}
\hline 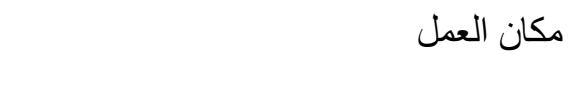 & 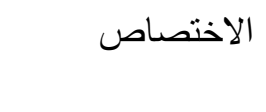 & 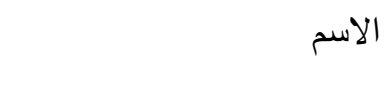 & العلمي & $ت$ \\
\hline دائرة التعليم الديني و الدراسات الإسلامية & 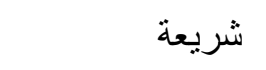 & محمد خضير الحمداني & أ.د. & 1 \\
\hline دائرة التعليم الديني و الدر اسات الإسلامية & شريعة & إحسان علو حسين & أ.د. & 2 \\
\hline الجامعة العر اقية/ كلية التربية للبنات & 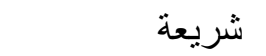 & حسام عبدالملك عبدالو احد & أ.د. & 3 \\
\hline الجامعة المستتصرية/ كليةالتربية الأساسية & لغة عربية & وجدان عبدالأمير & 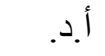 & 4 \\
\hline جامعة الموصل/ كلية الآداب & لغة عربية & عماد عبد يحيى & أ.د. & 5 \\
\hline وزارة التربية/ مديرية تربية ديالى & طر ائق تدريس & عصام عبدالعزيز المعدوري & أ.د. & 6 \\
\hline جامعة ديالى/ كلية العلوم الإسلامية & 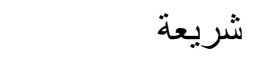 & حسين علي ريس & أ.د. & 7 \\
\hline جامعة ديالى/ كلية التربية الأساسية & علم النفس التربوي & مهند محمد عبد الستار & أ.د. & 8 \\
\hline جامعة بغداد/ متقاعد & فلسفة التربية & مقداد إسماعيل الدباغ & أ.د. & 9 \\
\hline جامعة بغداد/ كلية التربية & فلسفة التربية & أركان سعيد الجميلي & 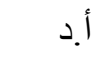 & 10 \\
\hline جامعة الأنبار / كلية التربية للعلوم الإنسانية & إرشاد تربوي & صبري بردان علي الحياني & أ.د & 11 \\
\hline جامعة ديالى/ متقاعد & إرشاد تربوي & ليث كريم حمد & أ.د & 12 \\
\hline
\end{tabular}


ملحق رقم (2) الاستبانة

المحترم الأستاذ الفاضل يروم الباحث در اسة الكفايات المهنية للإمام والخطيب، يرجى بيان رأيكم الكريم في هذه الفقرات، مع خالص الثكر و التقدير.

\begin{tabular}{|c|c|c|}
\hline الملاحظات & 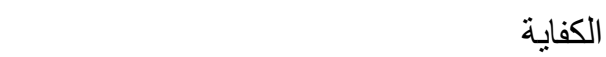 & $ت$ \\
\hline & التمكُُن المعرفي في مجالٍ التخصُّص. & 1 \\
\hline & التزود و الاطلاع الدائم على المعلوماتِ. & 2 \\
\hline & التزود بالمعارف العلمية و الرياضيات و اللغات. & 3 \\
\hline & الا هتمام بالثقافة العامة. & 4 \\
\hline & فهم ومتابعة الحركات الهدامة. & 5 \\
\hline & القدرة على جمع الآراء في المساءلة. & 6 \\
\hline & القدرة على الترجيح بين الآراء. & 7 \\
\hline & وضع درجات في مز اولة المهنة. & 8 \\
\hline & متابعة الأحداث. & 9 \\
\hline & تحديد سياقات للإشر اف و المتابعة. & 10 \\
\hline & حسن المظهر. & 11 \\
\hline & طيب الكلام وحسن التعامل. & 12 \\
\hline & التمكن من اللغة العربية. & 13 \\
\hline & سعة الصدر. & 14 \\
\hline & التمكُنن من مهار اتِ الو عظ و الإرشاد. & 15 \\
\hline & التمكن من الحوار الهادئ و المثمر. & 16 \\
\hline & احترام الآراء المخالفة. & 17 \\
\hline & القدرة على القيادة. & 18 \\
\hline & القدرةُ على تطويرِ ذاتِه. & 19 \\
\hline & القدرةُ على تبسيطِ المعارفِ و استخدام الأمثلة. & 20 \\
\hline
\end{tabular}


ARID International Journal of Educational and Psychological Sciences (AIJEPS) VOL: 2, NO. 4, July 2021

\begin{tabular}{|c|c|c|}
\hline الملاحظات & 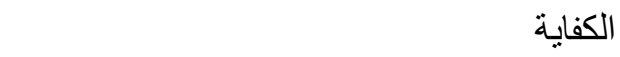 & ت \\
\hline & الاهتمام بالعلاقاتِ الإنسانيةِة في المجتمع. & 21 \\
\hline & التحرُّر من الصور التقليدية للإمام. & 22 \\
\hline & التجديد المستمر لطر ائق الإرشاد و النصح. & 23 \\
\hline & الاهتمام بالجو انب الترفيهية المباحة للشباب. & 24 \\
\hline & التو اصل الفعَّال مع الأسرةِ و المدرسة و المجتمع. & 25 \\
\hline & حب المهنة. & 26 \\
\hline & الر غبة في العمل. & 27 \\
\hline & الاتز ان العاطفي. & 28 \\
\hline & حب الوطن و الحرص على تقدمه. & 29 \\
\hline & الر غبة الصادقة في الإصلاح. & 30 \\
\hline
\end{tabular}


ملحق رقم (3) الاستبانة

المحترم الأستاذ الفاضل

يروم الباحث در اسة الكفايات المهنية للإمام و الخطيب، يرجى بيان رأيكم الكريم في هذه الفقرات، مع خالص الثكر والتقدير :

\begin{tabular}{|c|c|c|c|c|}
\hline 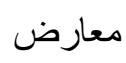 & 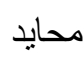 & 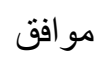 & أنو اع الكفايات & $ت$ \\
\hline & & & \multicolumn{2}{|c|}{ كفايات معرفية } \\
\hline & & & التمكُُن المعرفي في مجالِ التخصُّص. & 1 \\
\hline & & & التزود و الاطلاع الدائم على المعلوماتِ. & 2 \\
\hline & & & التزود بالمعارف العلمية و الرياضيات و اللغات. & 3 \\
\hline & & & الإلمام بالثقافة العامة الضروريةِ. & 4 \\
\hline & & & فهم ومتابعة الحركات الهدامة. & 5 \\
\hline & & & القدرة على جمع الآر اء في المساءلة. & 6 \\
\hline & & & القدرة على الترجيح بين الآر اء. & 7 \\
\hline & & & وضع درجات في مزاولة المهنة. & 8 \\
\hline & & & متابعة الأحداث. & 9 \\
\hline & & & تحديد سياقات للاشر اف و المتابعة. & 10 \\
\hline & & & \multicolumn{2}{|c|}{ كفايات تَرتَبط بالأداء } \\
\hline & & & حسن المظهر. & 1 \\
\hline & & & طيب الكلام وحسن التعامل. & 2 \\
\hline & & & التمكن من اللغة العربية. & 3 \\
\hline & & & سعة الصدر . & 4 \\
\hline & & & التمكُّن من مهار اتِ الو عظ و الإرششاد. & 5 \\
\hline & & & التمكن من الحوار الهاديء والمثر. & 6 \\
\hline & & & احترام الآراء المخالفة. & 7 \\
\hline & & & القدرة على القيادة. & 8 \\
\hline & & & القدرة على تطوير ذاتِه. & 9 \\
\hline
\end{tabular}




\begin{tabular}{|c|c|c|c|c|}
\hline معارض & محايد & 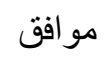 & أنواع الكفايات & ت \\
\hline & & & القدرة على تبسيطِ المعارفِ واستخدام الأمثلة. & 10 \\
\hline & & & الا هتمام بالعلاقاتِ الإنسانيةِة في المجتمع. & 11 \\
\hline & & & التحرُّر من الصور التقليدية للإمام. & 12 \\
\hline & & & التجديد المستمر لطرائق الإرشاد والنصح. & 13 \\
\hline & & & الا هتمام بالجو انب الترفيهية المباحة للشباب. & 14 \\
\hline & & & التو اصلِ الفعَّال مع الأسرةِ و المدرسة و المجتمع. & 15 \\
\hline & & & الإفادة من أساليب ووسائلِ التعليم. & 16 \\
\hline & & & الاهتمام بانسجام القول والفعل. & 17 \\
\hline & & & \multicolumn{2}{|c|}{ الكفايات الوجدانيَّة } \\
\hline & & & حب المهنة. & 1 \\
\hline & & & الر غبة في العمل. العل & 2 \\
\hline & & & الاتز ان العاطفي. & 3 \\
\hline & & & الاتزانُ الانفعالي. & 4 \\
\hline & & & حب الوطن و الحرص على تقدمه. & 5 \\
\hline & & & الر غبةُُ في التعلِِ. & 6 \\
\hline & & & الرغبة الصـادقة في الإصلاح. & 7 \\
\hline & & & تقويم الذات. & 8 \\
\hline & & & الإفادة من تجارب الناجحين. & 9 \\
\hline & & & تطابق القول و العمل. & 10 \\
\hline & & & تقديم المصالح العامة على الخاصة. & 11 \\
\hline & & & التعالي على صغائر الأمور. & 12 \\
\hline & & & القدرةُ على التعلُّم الذاتي. & 13 \\
\hline
\end{tabular}


ملحق رقم (4) السادة الخبر اء (عينة البحث)

\begin{tabular}{|c|c|c|c|c|}
\hline مكان العمل & 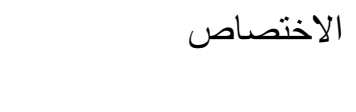 & 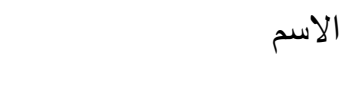 & العلمي & $ت$ \\
\hline دائرة التعليم الديني و الدر اسات الإسلامية & شريعة & محمد خضير الحمداني & أ.بد. & 1 \\
\hline دائرة التعليم الديني و الدر اسات الإسلامية & 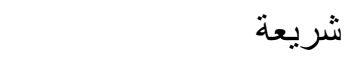 & إحسان علو حسين & 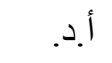 & 2 \\
\hline الجامعة العر اقية/ كلية التربية للبنات & 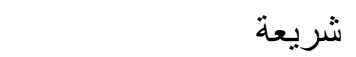 & حسام عبدالملك عبدالواحد & أ.د. & 3 \\
\hline الجامعة المستتصرية / كلية التربية الأساسية & لغة عربية & وجدان عبدالأمير & أ.د. & 4 \\
\hline جامعة الموصل/ كلية الآداب & لغة عربية & عماد عبد يحيى & أ.د. & 5 \\
\hline جامعة ديالى/ كلية التربية الأساسية & طر ائق تدريس التاريخ & عبد الرزاق عبداله & أ.د. & 6 \\
\hline وزارة التربية/ متقاعد & طر ائق تدريس الفيزياء & ثاني حسين خاجي & أ.د. & 7 \\
\hline وزارة التربية/ مديرية تربية ديالى & طر ائق تدريس الفيزياء & عصام عبد العزيز & 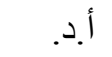 & 8 \\
\hline جامعة ديالى/ كلية التربية الأساسية & علم النفس التربوي & مهند محمدعبد الستار & أ.د. & 9 \\
\hline جامعة بغداد/ متقاعد & فلسفة التربية & مقداد إسماعيل الدباغ & أ.د. & 10 \\
\hline جامعة بغداد/ كلية التربية & فلسفة التربية & أركان سعيد الجميلي & أ.د & 11 \\
\hline وزارة التربية/ مديرية تربية صلاح الدين & لغة عربية & أسامة خلف العواد & أ.د & 12 \\
\hline جامعة ديالى/ كلية التربية المقداد & طرائق تدريس علوم & ماجد عبد الستار & أ.د. & 13 \\
\hline جامعة ديالى/ كلية التربية الأساسية & 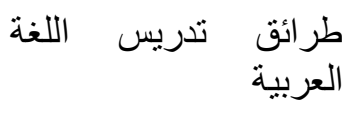 & محمد عبد الو هاب & أ.د. & 14 \\
\hline جامعة ديالى/ كلية التربية للعلوم الإنسانية & المناهج وطر ائق التدريس & أشو اق نصيف جاسم & أ.د & 15 \\
\hline جامعة ديالى/ كلية التربية للعلوم الإنسانية & المناهج وطر ائق التدريس & محمد إبر اهيم حسين & أ.د & 16 \\
\hline جامعة ديالى/ كلية التربية الأساسية & علم النفس التربوي & بشرى عناد التميمي & أ.د & 17 \\
\hline وزارة التربية/ المديرية العامة للمناهج & تربية خاصة & نجية إبر اهيم الدليمي & أم.د & 18 \\
\hline جامعة كركوك/ كلية التربية للعلوم الصرفة & 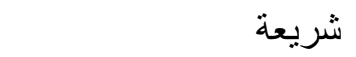 & ضياء سرحان العز اوي & أم.د & 19 \\
\hline وزارة التربية/ مديرية تربية ديالى & فلسفة تربية & رعد كريم & أم.د & 20 \\
\hline جامعة ديالى/ كلية التربية الأساسية & فلسفة التربية & موفق أيوب محسن & أم.د & 21 \\
\hline
\end{tabular}


ARID International Journal of Educational and Psychological Sciences (AIJEPS) VOL: 2, NO. 4, July 2021

\begin{tabular}{|c|c|c|c|c|}
\hline جامعة ديالى/ كلية التربية الأساسية & فلسفة التربية & 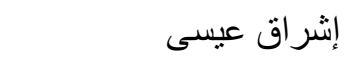 & أم.د & 22 \\
\hline جامعة ديالى/ كلية التربية للعلوم الإنسانية & فلسفة التربية & خالد سلمان الزبيدي & أو.م.د & 23 \\
\hline جامعة ديالى/ كلية التربية للعلوم الإنسانية & طرائق تدريس علوم & حسام يو سف & 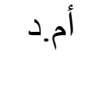 & 24 \\
\hline جامعة ديالى/ كلية الهندسة & 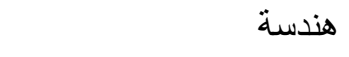 & نصر الله سلمان خلف & أم.د & 25 \\
\hline جامعة ديالى/ كلية التربية للعلوم الصرفة & رياضيات & عبد الستار جمعة & أ.م.د & 26 \\
\hline جامعة ديالى/ كلية التربية للعلوم الصرفة & حاسبات & سلام عبد الخالق نعمان & أ.م.د & 27 \\
\hline جامعة ديالى/ كلية العلوم & فيزياء & سلمان عبود الجبوري & أ.م.د & 28 \\
\hline وزارة التربية/ متقاعد & مشرف تربوي/ فيزياء & أحمد علي محمد الحانوتي & $\cdots$ & 29 \\
\hline وزارة التربية/ متقاعد & مدير ثانوية & فالح حسن الخزرجي & $\ldots$ & 30 \\
\hline
\end{tabular}




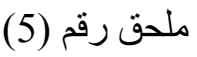
استبانة أساليب تطوير التعليم الديني

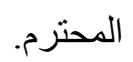
الأستاذ الفاضل

يروم الباحث دراسة أساليب تطوير النعليم الديني في العراق، يرجى بيان رأيكم الكريم في هذه الفقرات: (إضافة، حذف, تعديل)، مع

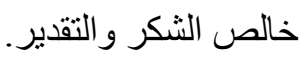

\begin{tabular}{|c|c|c|}
\hline 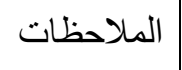 & 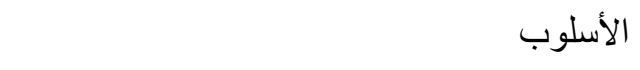 & $ت$ \\
\hline & \multicolumn{2}{|c|}{ استقطاب الطلبة المتفوقين } \\
\hline & دفع مخصصات مادية. & 1 \\
\hline & 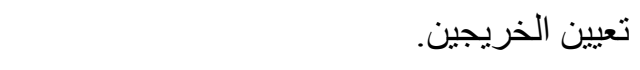 & 2 \\
\hline & فتح الدراسات العليا وقبول المتفوقين. & 3 \\
\hline & السماح بانتقال الطلبة لددارس التربية. & 4 \\
\hline & \multicolumn{2}{|c|}{ تأهيل المدرسين } \\
\hline & تفعيل مساءلة المدرس الأول في كل اختصاص. & 1 \\
\hline & دور ات في الكفاءة العلمية. & 2 \\
\hline & دورات في التنمية البشرية. & 3 \\
\hline & دور ات في طر ائق التدريس الحديثة. & 4 \\
\hline & دورات في مهارات استخدام العقل. & 5 \\
\hline & دورات في الدعوة والتوجيه و الإرشاد. & 6 \\
\hline & \multicolumn{2}{|c|}{ تطوير المناهج } \\
\hline & إضاقة المو اد العلمية. & 1 \\
\hline & إضافة اللغة الإنجليزية. & 2 \\
\hline & | اضضافة الرياضيات. & 3 \\
\hline & | إضافة الاجتماعيات. & 4 \\
\hline & | إضافة مو اد ثقافية. & 5 \\
\hline & \multicolumn{2}{|c|}{ وسائل وأساليب التندريس } \\
\hline & التعلم الذاتي. & 1 \\
\hline
\end{tabular}




\begin{tabular}{|l|r|r|}
\hline & 2 \\
\hline & 3 \\
\hline & 4 \\
\hline & 5 \\
\hline
\end{tabular}

ملحق رقم (6)

\begin{tabular}{|c|c|c|c|c|}
\hline 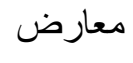 & 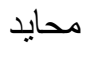 & مو افق & الأسلوب & $ت$ \\
\hline & & & \multicolumn{2}{|c|}{ استقطاب الطلبة المتفوقين } \\
\hline & & & دفع مخصصات مادية. & 1 \\
\hline & & & تعيين الخريجين. & 2 \\
\hline & & & فتح الدر اسات العليا وقبول المتفوقين. & 3 \\
\hline & & & السماح بانتقال الطلبة لمدارس التربية. & 4 \\
\hline & & & \multicolumn{2}{|c|}{ تأهيل المدرسين } \\
\hline & & & تفعيل مساءلة المدرس الأول في كل اختصاص. & 1 \\
\hline & & & دورات في الكفاءة العلمية. & 2 \\
\hline & & & دورات في التنمية البشرية. & 3 \\
\hline & & & دورات في طر ائق التدريس الحديثة. & 4 \\
\hline & & & دورات في مهار ات استخدام العقل. & 5 \\
\hline & & & دور ات في الدعوة والتوجيه و الإرشاد. & 6 \\
\hline & & & \multicolumn{2}{|c|}{ تطوير المناهج } \\
\hline & & & إضاقة المواد العلمية. & 1 \\
\hline & & & إضـافة اللغة الإنجليزية. & 2 \\
\hline & & & 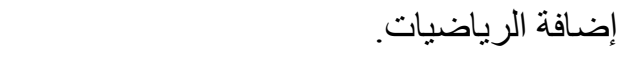 & 3 \\
\hline & & & إضـافة الاجتماعيات. & 4 \\
\hline
\end{tabular}




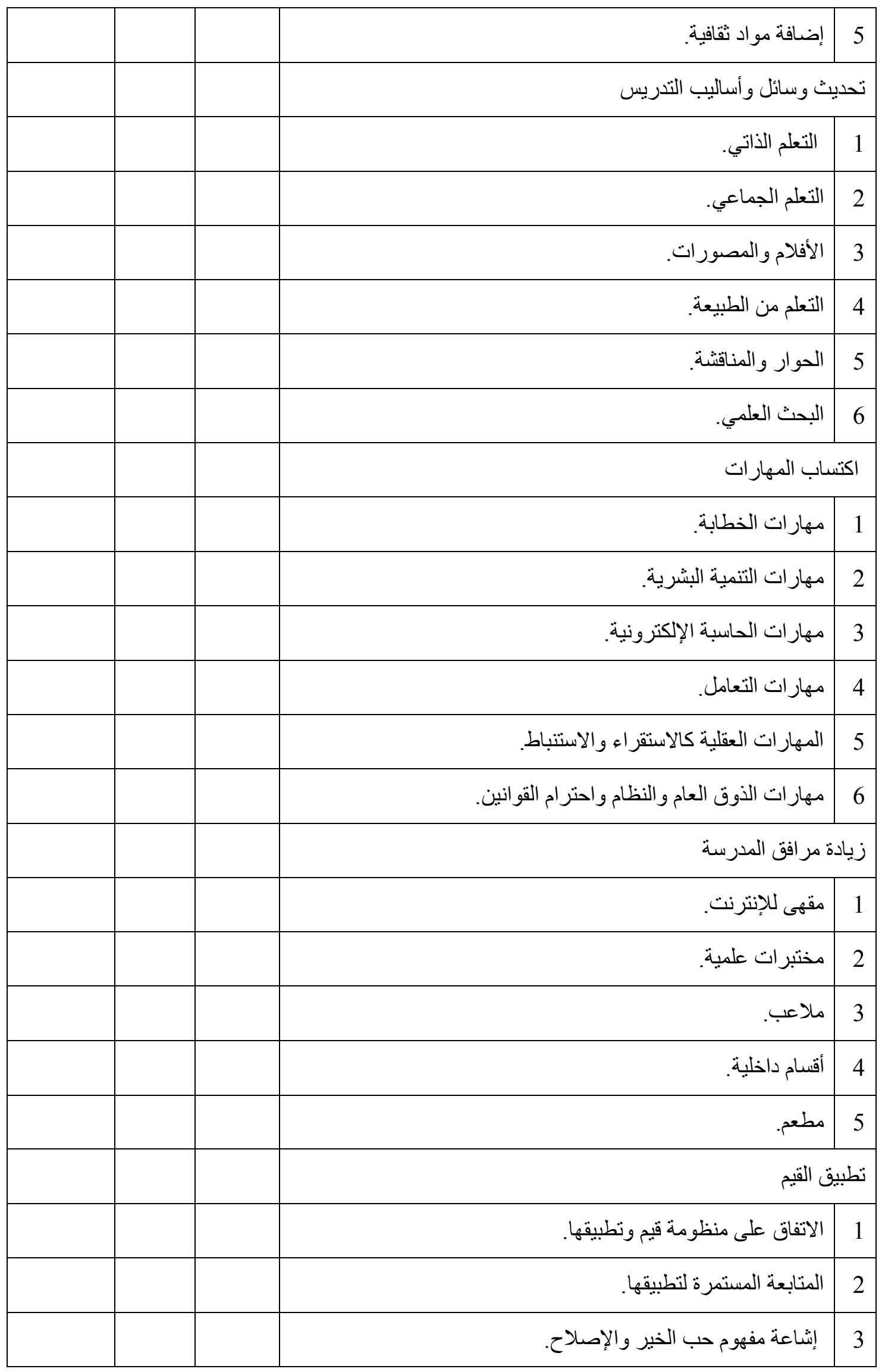


ARID International Journal of Educational and Psychological Sciences (AIJEPS) VOL: 2, NO. 4, July 2021

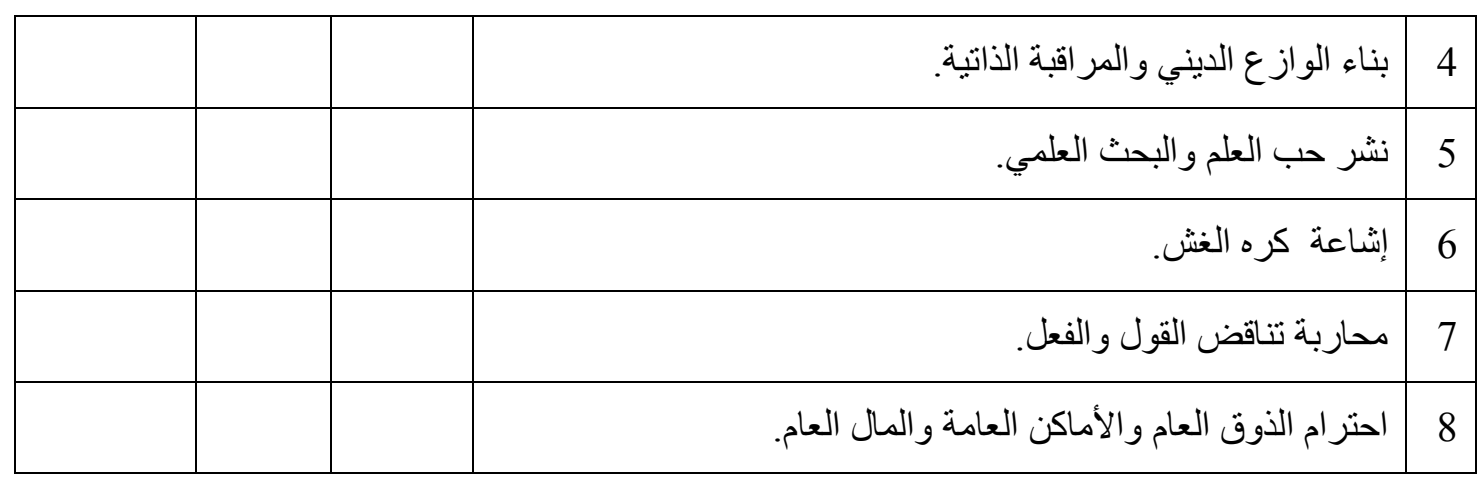

